\title{
Antiandrogen-induced cell death in LNCaP human prostate cancer cells
}

\author{
ECY Lee ${ }^{1}$, P Zhan ${ }^{1}$, R Schallhom ${ }^{1}$, K Packman ${ }^{1}$ and \\ M Tenniswood*,1 \\ ${ }^{1}$ Department of Biological Science, University of Notre Dame, Notre Dame, \\ IN 46556, USA \\ * Corresponding author: MPR Tenniswood, Tel: +574-631-3372; \\ Fax: +574-631-7413; E-mail: tenniswood.1@ @ nd.edu
}

Received 7.8.02; revised 26.10.02; accepted 6.12.02

Edited by DC Altieri

\begin{abstract}
Antiandrogens such as Casodex (Bicalutamide) are designed to treat advance stage prostate cancer by interfering with androgen receptor-mediated cell survival and by initiating cell death. Treatment of androgen sensitive, non-metastatic LNCaP human prostate cancer cells with $0-100 \mu \mathrm{M}$ Casodex or $0-10 \mathrm{ng} / \mathrm{ml} \mathrm{TNF}-\alpha$ induces cell death in $20-60 \%$ of the cells by $48 \mathrm{~h}$ in a dose-dependent manner. In cells treated with TNF$\alpha$, this is accompanied by the loss of mitochondrial membrane potential $\left(\Delta \Psi_{\mathrm{m}}\right)$ and cell adhesion. In contrast, cells treated with Casodex display loss of cell adhesion, but sustained mitochondrial dehydrogenase activity. Overexpression of $\mathrm{Bcl}-2$ in LNCaP cells attenuates the induction of cell death by TNF- $\alpha$ but not Casodex, suggesting that mitochondria depolarization is not required for the induction of cell death by Casodex. While both TNF- $\alpha$ and Casodex-induced release of cytochrome $c$ in LNCaP cell is predominantely associated with the translocation and cleavage of Bax, our data also suggest that Casodex induces cell death by acting on components downstream of decline of $\Delta \Psi_{m}$ and upstream of cytochrome $c$ release. Furthermore, while induction of both caspase- 3 and caspase- 8 activities are observed in TNF- $\alpha$ and Casodex-treated cells, a novel cleavage product of procaspase- 8 is seen in Casodex-treated cells. Taken together, these data support the hypothesis that Casodex induces cell death by a pathway that is independent of changes in $\Delta \Psi_{\mathrm{m}}$ and Bcl2 actions and results in an extended lag phase of cell survival that may promote the induction of an invasive phenotype after treatment.
\end{abstract}

Cell Death and Differentiation (2003) 10, 761-771. doi:10.1038/ sj.cdd. 4401228

Keywords: casodex; prostate cancer; LNCaP; Bcl-2; Bax; cytochrome $c$; caspase; mitochondrial membrane potential

Abbreviations: AR, androgen receptor; AFC, 7-amino-4trifluoromethyl coumarin; ANT, adenine nucleotide translocator; DISC, death-inducing signaling complex; $\Delta \Psi_{\mathrm{m}}$, mitochondrial membrane potential; GAPDH, glyceraldehyde-3-phosphate de- hydrogenase; IMM, inner mitochondrial membrane; MMP, matrix metalloprotease; MTT, 3-[4,5-dimethylthiazol-2-yl]-2,5-diphenyl tetrazolium bromide; OMM, outer mitochondrial membrane; PI, propidium iodine; $\mathrm{PT}$, permeability transition; $\mathrm{T}_{3}, 3,3^{\prime}, 5$-triiodothyronine; t-Bax, truncated Bax; TMRE, tetramethylrhodamine ethyl ester; TNF- $\alpha$, tumor necrosis factor- $\alpha$; VDAC, voltagedependent anion channel.

\section{Introduction}

Active cell death, or apoptosis, plays a central role in maintaining tissue homeostasis and proper disposal of damaged or excess cells, including the epithelial cells of the prostate after castration or administration of antiandrogens. ${ }^{1}$ Casodex, an antiandrogen used in prostate cancer therapy, is designed to reduce tumor size by interfering with normal androgen receptor (AR)-mediated processes that ensure prostate cell survival and by triggering tumor cells to undergo apoptosis. ${ }^{2}$ However, tumors treated with antiandrogens ultimately become hormone refractory and have an increase propensity for metastasis. ${ }^{3-6}$

Apoptosis is usually manifested by one of two major execution pathways downstream of death signals: the death receptor-mediated pathway, often referred to as the extrinsic pathway, and the mitochondrial pathway or intrinsic pathway. ${ }^{7}$ The death receptor-mediated pathway is activated upon ligand binding of cell surface death receptors such as tumor necrosis factor- $\alpha$ (TNF- $\alpha$ ), initiating ligand-induced receptor trimerization and the formation of death-inducing signaling complex (DISC).$^{8,9}$ Once caspase-8, the initiator caspase, is recruited in zymogen form to the DISC, it is autocatalytically processed and released from the complex to the cytosol as active tetramer to transactivate a number of downstream executioner caspases including the dominant executioner caspase, caspase-3. ${ }^{10-12}$ Caspase- 3 in turn mediates the activation of a number of proteases and nucleases that are responsible for the loss of vital cell function, the condensation of the nucleus, and fragmentation of genomic DNA. ${ }^{13-15}$

Like other death-promoting stimuli such as oxidative stress, calcium overload and ATP depletion, caspase-8 activation from the death-receptor pathway can also trigger the mitochondrial pathway that involves the release of cytochrome $c$ from the intermembrane space to the cytosol, lost of mitochondrial membrane potential $\left(\Delta \Psi_{\mathrm{m}}\right)$, hyperdensity of the matrix, and shrinkage of the organelle. ${ }^{16-18}$ Once released from the mitochondria, cytochrome $c$ assembles with Apaf-1 and procaspase- 9 to form the apoptosome, which leads to the activation of caspase-3 and other executioner caspases that are responsible for the degradation of a variety of structural and housekeeping proteins, resulting in the disassembly of the cell. ${ }^{19}$

Key regulators of the mitochondrial pathway include both antiapoptotic and proapoptotic members of the Bcl-2 family of proteins. The antiapoptotic $\mathrm{Bcl}-2$ subfamily includes $\mathrm{Bcl}-2$ and $\mathrm{Bcl}-\mathrm{x}_{\mathrm{L}}$, which have been shown to block the release of 
cytochrome $c$ and the decline in $\Delta \Psi_{\mathrm{m}}$ by heterodimerizing with proapoptotic proteins and neutralizing their activities. ${ }^{7}$ The proapoptotic Bcl-2 subfamily includes Bax and Bak, are translocated from their cytoplasmic location to the mitochondria, where they induce the release of cytochrome $c$ either through the formation of a multimeric channel or direct interaction with the voltage-dependent anion channel (VDAC) at the outer mitochondrial membrane (OMM). ${ }^{20,21}$ Cleavage of Bax to truncated t-Bax has also been shown to increase its cytotoxicity and has been implicated in facilitating the assemble of adenine nucleotide translocator (ANT) at the inner mitochondrial membrane (IMM) and VDAC at the OMM in the formation of the mitochondrial permeability transition (PT) pore complex, which is responsible for the dissipation of $\Delta \Psi_{\mathrm{m}}$, matrix swelling, and the release of cytochrome $c .^{22-24}$

To investigate the mechanism of Casodex-induced cell death in prostate cancer cells, we have compared specific intracellular events in the hormone-sensitive, nonmetastatic human prostate LNCaP cell line before and after treatment with Casodex and TNF- $\alpha$. As Bcl-2 overexpression has been frequently observed in hormone refractory prostate tumors, ${ }^{25}$ we have also examined the effect of $\mathrm{Bcl}-2$ overexpression on the induction of cell death by Casodex. Unlike TNF- $\alpha$, Casodex induces cell death through Bax-dependent and -independent pathways that involve components downstream of decline of $\Delta \Psi_{\mathrm{m}}$ and upstream of cytochrome $c$ release.

\section{Results}

\section{Sustained mitochondrial dehydrogenase activity and limited loss of $\Delta \Psi_{m}$ in Casodex-induced cell death}

To investigate the mechanism of Casodex-induced cell death in LNCaP cells, we first compared specific morphological events in LNCaP cells after treatment with Casodex and TNF$\alpha$. TNF- $\alpha$ induces cell death in LNCaP cells in a timedependent manner as measured by crystal violet assay which monitors changes in number of attached cells, and MTT which monitors changes in mitochondrial dehydrogenase activities. When LNCaP cells are treated with $5 \mathrm{ng} / \mathrm{ml}$ TNF- $\alpha$ for $24-72 \mathrm{~h}$, $20-60 \%$ cell death is observed by both assays (Figure 1, panel A), suggesting that the loss of cell mitochondrial activity and cell attachment are coordinated events. When LNCaP cells are treated with $100 \mu \mathrm{M}$ Casodex, a similar timedependent decrease in attached viable cells is seen for the first $24 \mathrm{~h}$. However, after this initial decrease to $70 \%$ viability in mitochondrial dehydrogenase activity during the first $24 \mathrm{~h}$, a $\quad 5 \mathrm{ng} / \mathrm{mL}$ TNF- $\alpha$

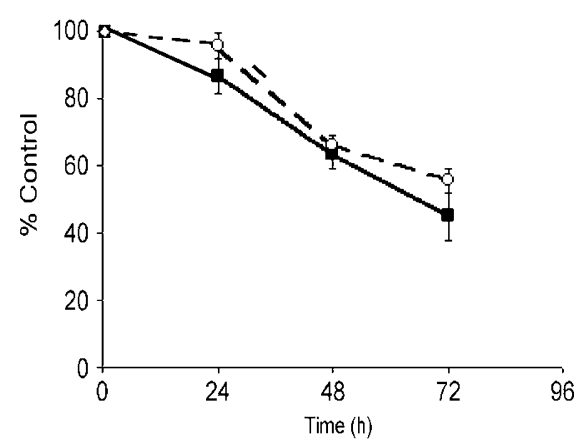

c

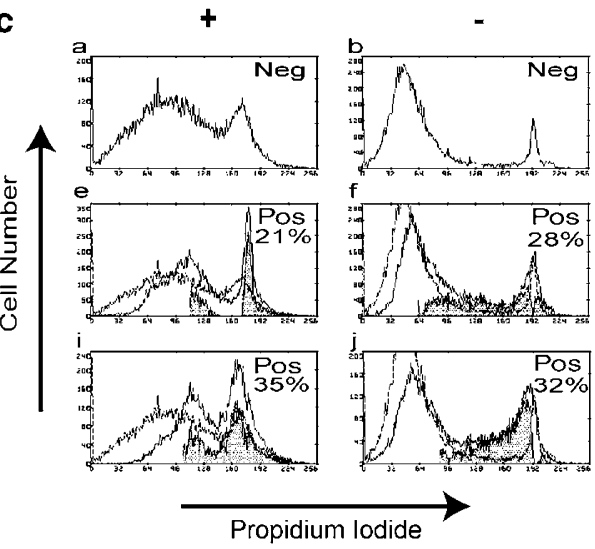

b $\quad 100 \mu \mathrm{M}$ Casodex
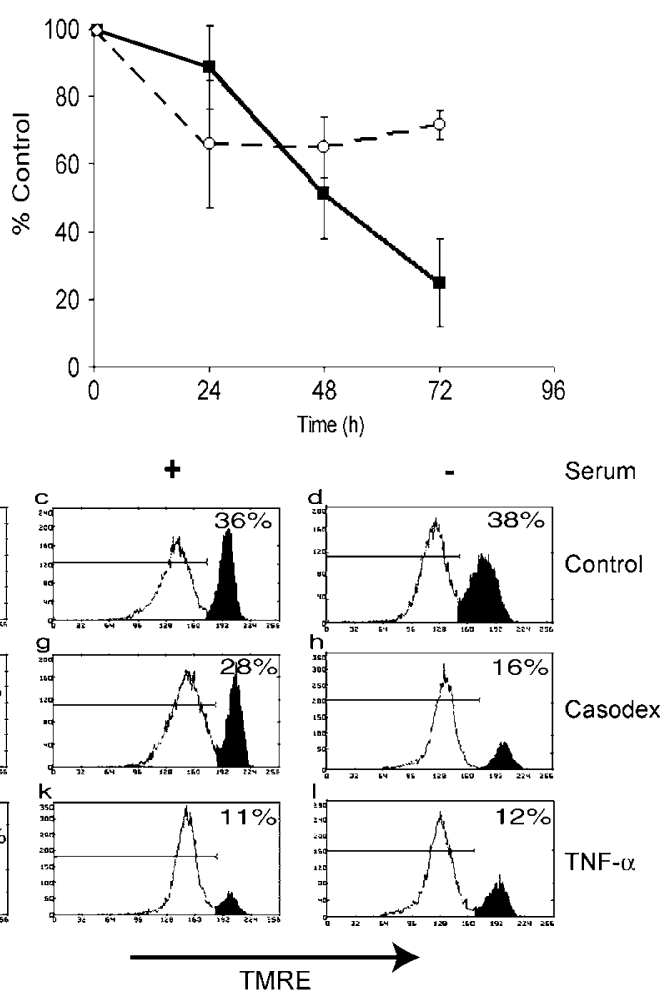

Figure 1 Effects of TNF- $\alpha$ and Casodex on cell adhesiveness, mitochondrial dehydrogenase activities and mitochondrial membrane potential $\left(\Delta \Psi_{\mathrm{m}}\right)$. LNCaP cells were treated with $5 \mathrm{ng} / \mathrm{ml}$ TNF- $\alpha$ (panel A) or $100 \mu \mathrm{M}$ Casodex (panel B) for 24,48 and $72 \mathrm{~h}$ in Gc medium. Cell adhesiveness was determined by crystal violet ( $\mathbf{\square}$ ) and mitochondrial dehydrogenase activity was measured using MTT assay $(O)$. Resultes are expressed as mean \pm S.D. of three independent experiments. (panel C) LNCaP cells were treated with control vehicle $(a-d), 50 \mu \mathrm{M}$ Casodex (e-h), or $5 \mathrm{ng} / \mathrm{ml}$ TNF- $\alpha(i-l)$ for $48 \mathrm{~h}$ in serum-containing medium (a, c, e, g, i, k) or serum free Gc medium ( $b, d, f, h, j, I)$. Cell death was measured by PI-exclusion $(a, b, e, f, i, j)$. Shaded area represents the induction of cell death calculated by Multiples AV software as lapped increase in PI staining due to cell membrane permeability following treatment. $\Delta \Psi_{\mathrm{m}}$ was measured by TMRE-inclusion (c, d, g, h, k, l). Percentage of cells that maintains $\Delta \Psi_{\mathrm{m}}$ was calculated by determining the integral of shaded area (which represents high TMRE staining) versus total area using Multiplus AV software 
there is no further significant change in mitochondrial dehydrogenase activity (Figure 1, panel B). This suggests that Casodex and TNF- $\alpha$ induce cell death by mechanisms that are substantially different.

The loss of $\Delta \Psi_{\mathrm{m}}$ is a critical intracellular event for apoptosis executed through the intrinsic mitochondrial pathway. As shown in Figure 1, panel $\mathrm{C}$, compared to vehicle-treated control cells (Figure 1, panel C; a-d), TNF- $\alpha$ induces cell death and reduction of $\Delta \Psi_{\mathrm{m}}$ in both serum-containing and serumfree medium (Figure 1, panel $\mathrm{C} ; \mathrm{i}-\mathrm{I}$ ). In contrast, Casodex only induces the reduction of $\Delta \Psi_{m}$ in serum-free medium (Figure 1, panel C; g, h), despite inducing similar amounts of cell death in both media (Figure 1, panel C; e, f). This suggests that Casodex is able to induce cell death without causing the dissipation of $\Delta \Psi_{\mathrm{m}}$ if trophic factors are present in the serum to attenuate the process. This also suggests that, like the reduction of mitochondrial activities, the reduction of $\Delta \Psi_{\mathrm{m}}$ is not required for Casodex-induced cell death.

\section{Induction of viability in non-adherent cells treated with Casodex}

One possible explanation for these observations is that when LNCaP cells are treated with Casodex, a significant number of cells detach from the cell culture monolayer without the concomitant loss of mitochondrial dehydrogenase activity and are thus, by definition, still viable (Figure 1, panel B). To verify this, anchorage-free cell viability of nonadherent LNCaP cells detached from the cell culture monolayer after treatment with control vehicle, $50 \mu \mathrm{M}$ Casodex or $5 \mathrm{ng} / \mathrm{ml} \mathrm{TNF-} \alpha$ was measured in a soft agar assay. As shown in Figure 2, Casodex induces at least a three-fold increase in the viability of nonadherent cells as compare to vehicle-treated cells. In contrast, when cells are treated with TNF- $\alpha$, there is no evidence of viable nonadherent cells after treatments, demonstrating that while inducing cell death in the majority of the cell population, Casodex induces a small portion to detach from monolayer while maintaining viability.

\section{Overexpression of $\mathrm{Bcl}-2$ in $\mathrm{LNCaP}$ cells}

$\mathrm{Bcl}-2$ is thought to play an important role in both the intrinsic mitochondrial pathway and the progression of prostate cancer. To investigate the role of $\mathrm{Bcl}-2$ in Casodex-induced cell death, we stably transfected LNCaP cells with human Bcl2 and isolated two independent clones, LNCaP-B10 and LNCaP-B19 that overexpress Bcl-2. The majority of overexpressed $\mathrm{Bcl}-2$ protein in these two clones is localized to NNMF, consistent with previous suggestions that $\mathrm{Bcl}-2$ associates with mitochondria to prevent $\Delta \Psi_{\mathrm{m}}$ disruption and cytochrome $c$ release (Figure 3, panel A). Moreover, these transfected clones do not have altered level of expression of cytochrome $c$ (data not shown), making these clones suitable models for studying the role of $\mathrm{Bcl}-2$ in the attenuation of the intrinsic mitochondrial pathway in Casodex-induced cell death.

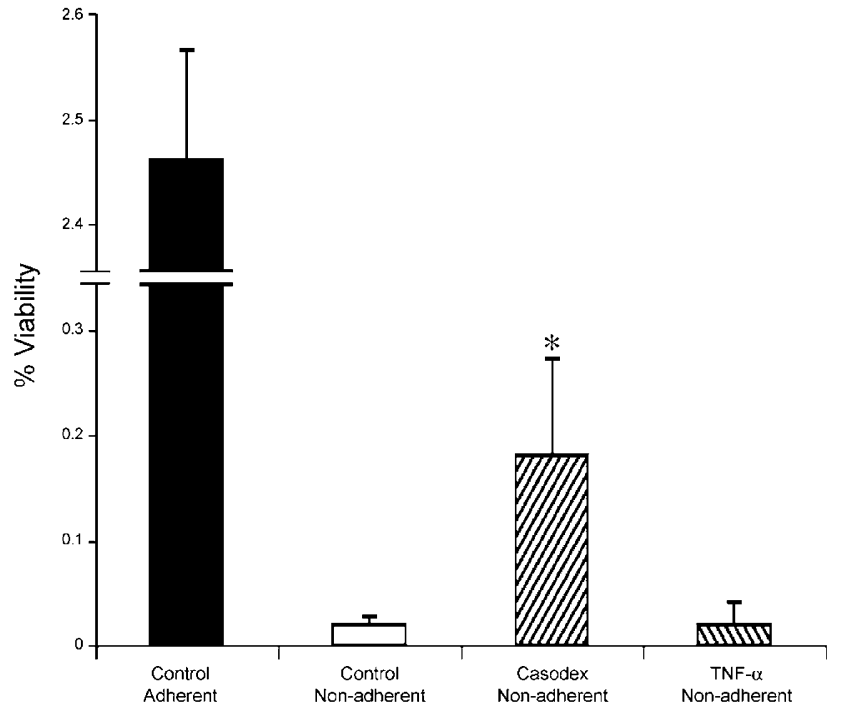

Figure 2 Viability of cells detached from the cell monolayer after treatment with TNF- $\alpha$ and Casodex. LNCaP cells were treated in triplicate with control vehicle, $50 \mu \mathrm{M}$ Casodex or $5 \mathrm{ng} / \mathrm{ml}$ TNF- $\alpha$ for $72 \mathrm{~h}$ in Gc medium. Viabilities of cells detached from the cell monolayer expressed as mean \pm S.D. were determined by anchorage-free cell viability assay. ${ }^{*} P<0.05$; Casodex-treated versus control vehicle or TNF- $\alpha$-treated as evaluated by analysis of variance

a

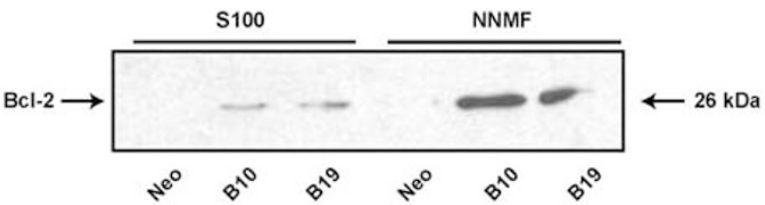

b

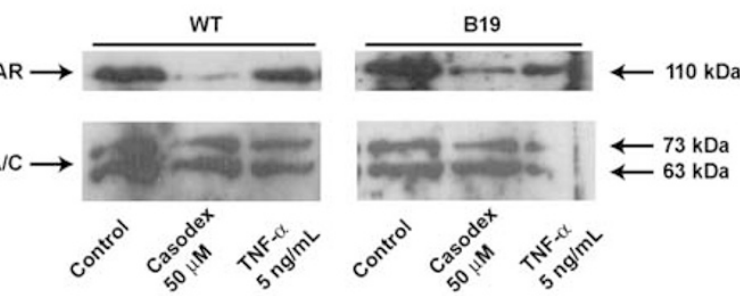

C
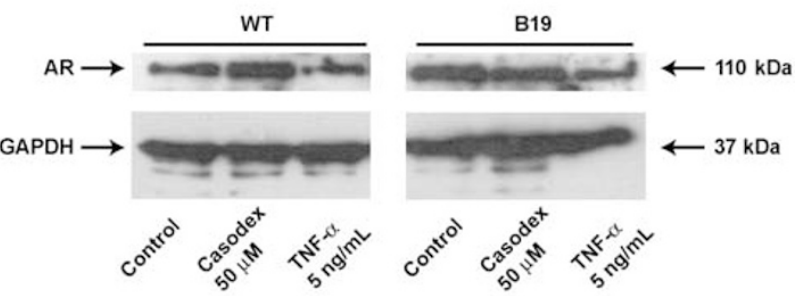

Figure 3 Nuclear translocation of androgen receptor (AR) in Bcl-2-overexpressing LNCaP cells after treatment with TNF- $\alpha$ and Casodex. (panel A) S100 and NNMF were isolated from empty vector transfected (Neo) and $\mathrm{Bcl}-2$ overexpressing cells (B10 and B19), separated by SDS-PAGE, transferred to nitrocellulose and immunoblotted with anti-Bcl-2 antibody (clone 124; Upstate Biotech.) as described in experimental procedures. (panels B and C) Nuclear fractions (panel B) and total cell lysate (panel C) were isolated from WT and Bcl-2 overexpressing (B19) LNCaP cells treated with control vehicle, $50 \mu \mathrm{M}$ Casodex or $5 \mathrm{ng} / \mathrm{ml} \mathrm{TNF}-\alpha$ for $48 \mathrm{~h}$ in Gc medium. Fractions $(100 \mu \mathrm{g})$ were separated by SDS-PAGE, transferred to nitrocellulose and immunoblotted with anti-AR antibody (PG-12, Upsate Biotech.) as described in experimental procedures 


\section{Nuclear localization but not expression of AR is altered by Casodex}

To determine the subcellular localization and level of expression of AR after treatment with Casodex and TNF- $\alpha$, total cell lysate and nuclear fractions of wild-type (WT) and $\mathrm{Bcl}-2$-overexpressing (B19) $\mathrm{LNCaP}$ cells after treatment were prepared. Previous report has suggested that binding of Casodex to the mutated AR of $\mathrm{LNCaP}$ cells either restricts the nuclear translocation or induces the rapid degradation of the receptor. ${ }^{26} \mathrm{AR}$ is barely detectable in the nuclear fraction after treatment with Casodex (Figure 3, panel B). Untreated WT and $\mathrm{Bcl}-2$ overespressing (B19) LNCaP cells express substantial levels of $A R$ in the nuclear fraction, both before and after treatment with $5 \mathrm{ng} / \mathrm{ml}$ TNF- $\alpha$. In contrast, total level of expression of AR in both WT and Bcl-2 overexpressing (B19) LNCaP cells is not affected by Casodex treatment (Figure 3, panel C). In contrast, TNF- $\alpha$ treatment of both WT and B19 LNCaP cells only slightly decreases the level of AR, suggesting that Casodex acts on the androgen receptormediated pathway through reducing the nuclear localization of AR but not its expression.

\section{Bcl-2 overexpression attenuates cell death induced by TNF- $\alpha$ but not Casodex}

As shown in Figure 4, TNF- $\alpha$ induces the formation of apoptotic bodies only in WT (LNCaP-WT) but not in Bcl-2 overexpressing (LNCaP-B10) LNCaP cells (Figure 4, panel A; c, f). In contrast, Casodex induces the formation of apoptotic bodies in both WT (LNCaP-WT) and Bcl-2 overexpressing (LNCaP-B10) LNCaP cells (Figure 4, panel A; b, e). This suggested that Bcl-2overexpression, which inhibits the release of cytochrome $c$ and the dissipation of $\Delta \Psi_{\mathrm{m}}$, rescues LNCaP-B10 cells from TNF- $\alpha$ but not Casodex-induced cell death. To verify this, cell viability of LNCaP-WT, LNCaP-B10, LNCaP-B19 and LNCaP-Neo cells after treatment with control vehicle, Casodex or TNF- $\alpha$ was measured. While overexpression of Bcl-2 in LNCaP cells attenuates TNF- $\alpha$-induced reduction in cell viability (Figure 4, panel C), Casodex-induced reduction in cell viability is not altered by Bcl-2 overexpression (Figure 4, panel B). This demonstrates that Casodex induces cell death in the B10 and $\mathrm{B} 19$ cell lines, despite the elevated level of $\mathrm{Bcl}-2$, and suggests that Casodex induces cell death by acting on components of the death pathway downstream of Bcl-2. $\sum_{3}^{a}$
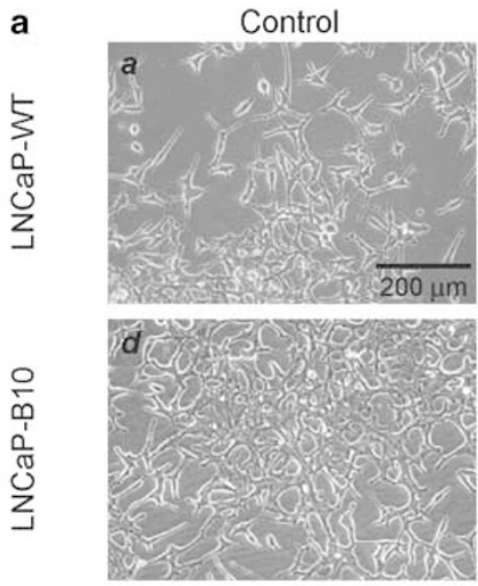

b

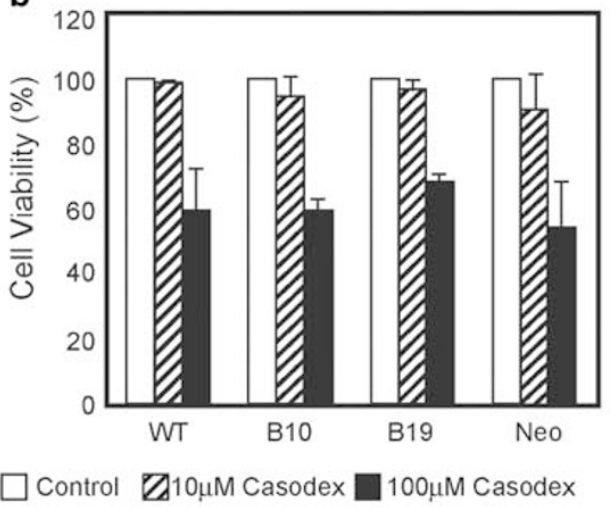

Casodex $100 \mu \mathrm{M}$
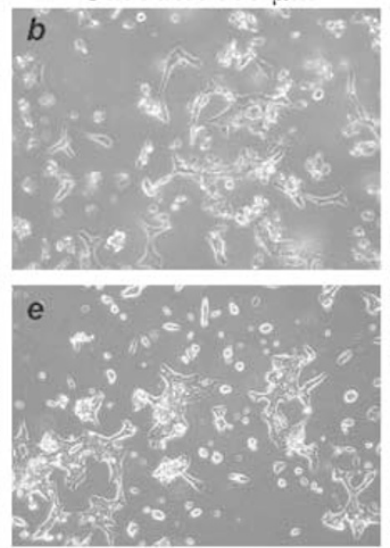

$\mathrm{TNF}-\alpha 10 \mathrm{ng} / \mathrm{mL}$
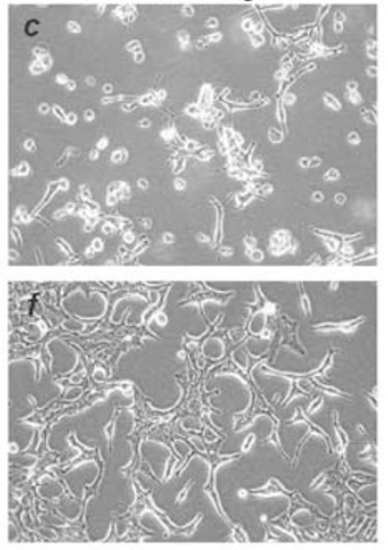

C

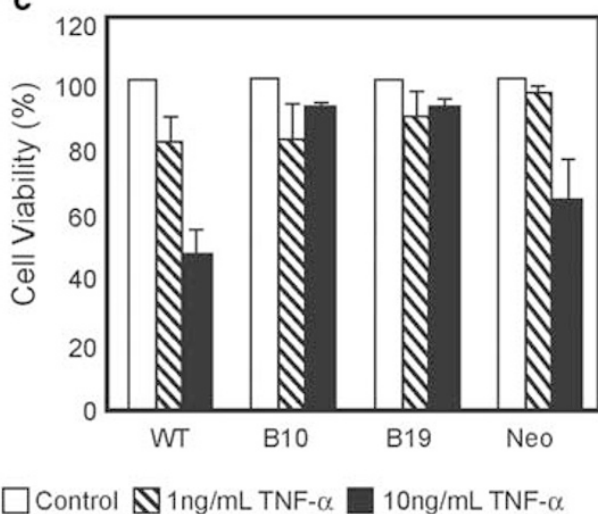

Figure 4 Effects of Casodex and TNF- $\alpha$ on cell viability of LNCaP cells overexpressing Bcl-2. (panel A) Phase contrast photograph of WT (LNCaP-WT; a, b, c) or Bcl2-overexpressing (LNCaP-B10; d, e, f) LNCaP cells treated with control vehicle (a, d), $100 \mu \mathrm{M}$ Casodex (b, e) or $10 \mathrm{ng} / \mathrm{ml}$ TNF- $\alpha$ (c, f) for $72 \mathrm{~h}$ in Gc medium (Bar: $200 \mu \mathrm{m})$. WT, Bcl-2-overexpressing (B10 and B19), and empty vector-transfected (Neo) LNCaP cells were treated with 10 or $100 \mu \mathrm{M} \mathrm{Casodex} \mathrm{(panel} \mathrm{B)} \mathrm{or} 1$ or $10 \mathrm{ng} / \mathrm{ml}$ TNF- $\alpha$ (panel C), for $72 \mathrm{~h}$ in Gc medium. Cell viabilities from three independent experiments expressed as mean \pm S.D. were determined by MTT assay (Sigma) 
a
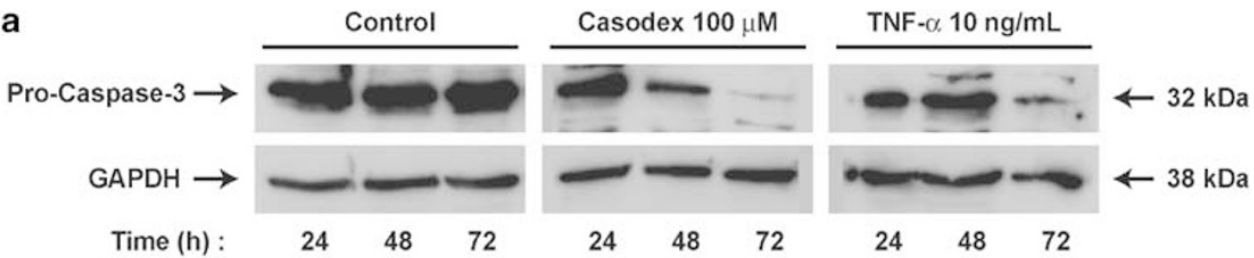

b
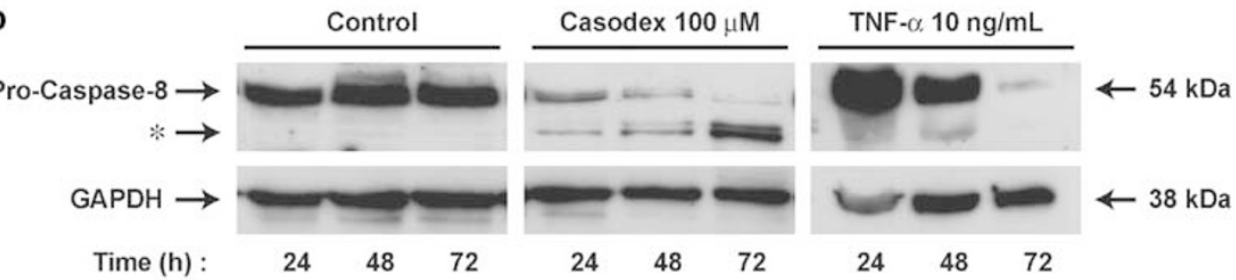

c

Caspase-3

(DEVD-CHO Inhibitable) Activity

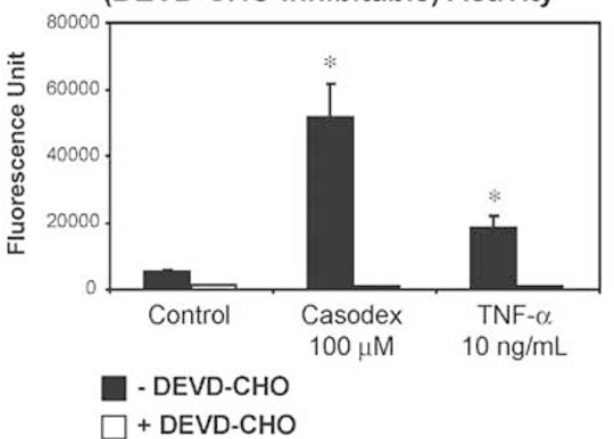

d Caspase-8

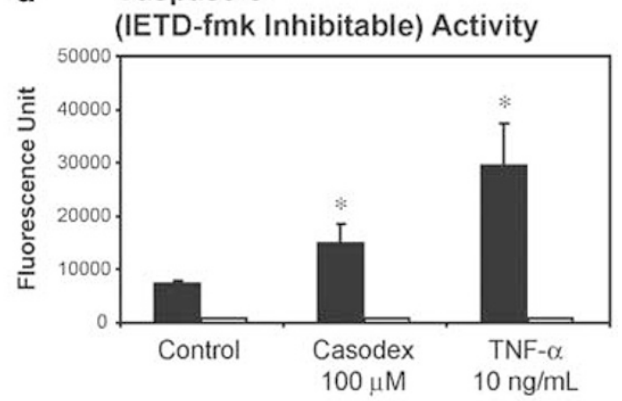

- IETD-fmk

+ IETD-fmk

Figure 5 Activation of caspase-3 and capase-8 after treatment with TNF- $\alpha$ and Casodex. Total cell lysate from WT LNCaP cells treated with control vehicle, $10 \mathrm{ng} / \mathrm{ml}$ TNF- $\alpha$ or $100 \mu \mathrm{M}$ Casodex for 24,48 and $72 \mathrm{~h}$ in Gc medium were separated on SDS-PAGE, transferred to nitrocellulose, and immunobloted with anticaspase-3 (06735, Upstate Biotech.) (panel A) or anticaspase-8 (clone 5F7, Upstate Biotech.) antibody (panel B). Cytosolic extracts of WT LNCaP cells $\left(1 \times 10^{6}\right.$ cells) treated with control vehicle, $10 \mathrm{ng} / \mathrm{ml}$ TNF- $\alpha$ or $100 \mu \mathrm{M}$ Casodex for $48 \mathrm{~h}$ in Gc medium were incubated with DEVD-AFC (panel C) or IETD-AFC (panel D) for $1 \mathrm{~h}$ at $37^{\circ} \mathrm{C}$ and analyzed by fluorescence spectrophotometry. DEVDase activities and IETDase activities represented as mean \pm s.d. were determined by ApoAlert Caspase Fluorescent Assay. ${ }^{*} P<0.05$; Casodex or TNF- $\alpha$-treated versus control vehicle-treated as evaluated by analysis of variance

\section{Differential activation of caspases by Casodex and TNF- $\alpha$}

Caspase-3 and capase-8 are proteolytically cleaved and activated directly downstream of the mitochondrial pathway or the death receptor pathway, respectively. ${ }^{27,28}$ As shown in Figure 5, panel A, procaspase-3 is proteolytically cleaved and activated after treatment with $100 \mu \mathrm{M}$ Casodex or $10 \mathrm{ng} / \mathrm{ml}$ TNF- $\alpha$. In particular, the activation of caspase-3 in LNCaP cells by Casodex is observed $24-48 \mathrm{~h}$ after treatment, preceding that seen after TNF- $\alpha$ treatment where the activation does not occurs until $48-72 \mathrm{~h}$. Proteolytic cleavage of procaspase- 8 occurs between 48 and $72 \mathrm{~h}$ after treatment with Casodex or TNF- $\alpha$. However, Casodex treatment induces a novel $45 \mathrm{kDa}$ cleavage product of procaspase-8 (Figure 5, panel B). To determine whether this cleavage product is enzymatically active, both caspase- 3 and capase-8 activities of LNCaP cells were measured using fluorogenic substrate DEVD-AFC and IETD-AFC respectively, before and after treatment with TNF- $\alpha$ or Casodex. Casodex induces a higher DEVDase activity than TNF- $\alpha$ in LNCaP cells after $48 \mathrm{~h}$ of treatment (Figure 5, panel $\mathrm{C}$ ), agreeing with the Western blot analysis (Figure 5, panel A). Furthermore, even though Casodex induces unusual cleavage of procaspase-8, the cleavage product retains IETDase activity, although at a reduced level compared to TNF- $\alpha$ (Figure 5, panel D).

\section{Casodex-induced release of cytochrome C involves both Bax-dependent and -independent pathways}

The release of cytochrome $c$ from mitochondria to cytosol is one of the hallmarks for apoptosis. Since the translocation of Bax from the cytosolic to the mitochondrial faction is often associated with the release of cytochrome $c$ during apoptosis, ${ }^{29}$ we examined the subcellular redistribution of cytochrome $c$ and Bax after Casodex treatment of LNCaP cells. S100 and NNMF were isolated from WT LNCaP cells after treatment with Casodex or TNF- $\alpha$. ATP synthase- $\alpha$ was not detectable in S100, demonstrating that the S100 cytosolic fraction is free of mitochondrial contamination (Figure 6, panels $A$ and $B$ ). Increased levels of cytochrome $c$ are detected in S100 after Casodex or TNF- $\alpha$ treatment (Figure 6, 


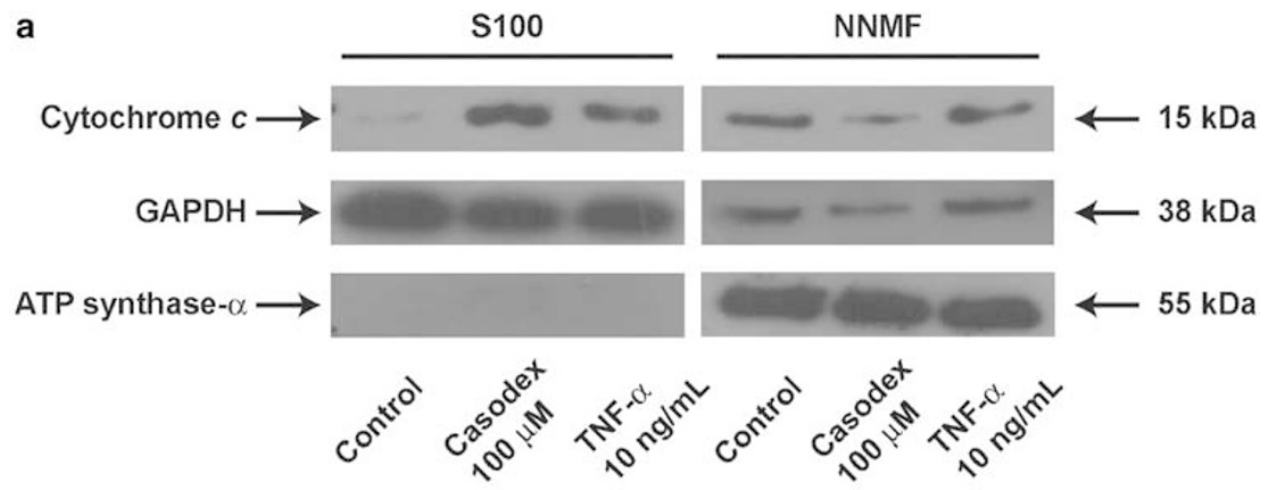

b

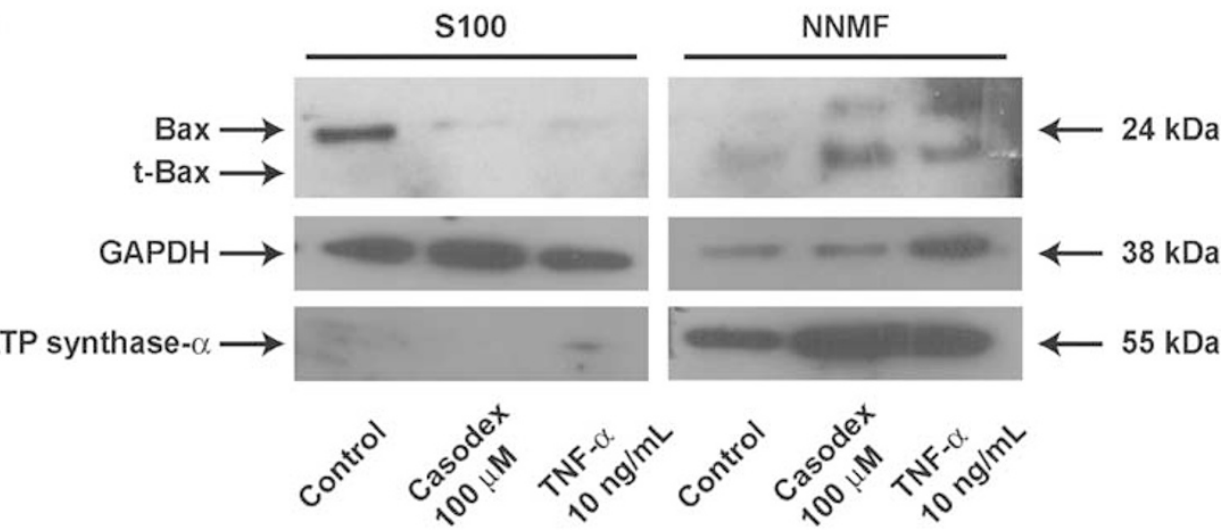

Figure 6 Translocation of cytochrome $c$ and Bax after treatment with TNF- $\alpha$ and Casodex. S100 and NNMF isolated from WT LNCaP cells treated with control vehicle, $10 \mathrm{ng} / \mathrm{ml}$ TNF- $\alpha$ or $100 \mu \mathrm{M}$ Casodex for $48 \mathrm{~h}$ in Gc medium were separated on SDS-PAGE, transferred to nitrocellulose, and immunoblotted with anticytochrome $c$ (7H8.2C12, PharMingen) (panel A) or anti-Bax (13666E; PharMingen) (panel B) antibody. Anti-ATP synthase- $\alpha$ (A11177; Molecular Probes) and anti-GAPDH (6G5; Biogenesis) antibodies were used to immunoblot for the level of mitochondrial and cytoplasmic contamination respectively

panel A), suggesting that cytochrome $c$ is relocalized from the mitochondria to the cytosol upon treatment. Furthermore, decreased levels of Bax in S100 and increased level of both Bax and truncated Bax (t-Bax) in NNMF occur after treatment with both Casodex and TNF- $\alpha$ (Figure 6, panel B), demonstrating that in LNCaP cells, both Casodex and TNF- $\alpha$ induce the cleavage of Bax and its localization to the mitochondria. Further examination by immunofluorescence microscopy suggested that Casodex-induced release of cytochrome $c$ is executed predominately by a Bax-dependent mechanism. As shown in Figure 7, in control vehicle-treated cells (Figure 7; ad), punctated cytochrome $c$ staining is observed and Baxstaining is undetectable, consistent with their respective mitochondrial and cytoplasmic location in preapoptotic cells. Upon induction of apoptotic signal by TNF- $\alpha$ (Figure 7; e-h) or Casodex (Figure 7; i-l; m-p), diffuse cytoplasmic cytochrome $c$ staining is detected throughout the cell, which obscure the nuclei, consistent with redistribution of cytochrome $c$ from mitochondria to cytoplasm (Figure $7 ; \mathrm{g}, \mathrm{k}, \mathrm{o}$ ). This is accompanied by translocation of Bax from cytoplasm to mitochondria as evidenced by punctuated Bax staining in cells treated with TNF- $\alpha$ or Casodex (Figure $7 ; \mathrm{f}, \mathrm{j}, \mathrm{n}$ ). This is followed by chromatin condensation as identified by Hoechst nuclear staining and cytosolic vacuolization and nuclear condensation (Figure 7; e, i, m). The presence of cytochrome $c$ release in the apparent absence of Bax translocation is seen in a small proportion ( $<20 \%$ ) of cells treated with casodex but not TNF- $\alpha$ (Figure $7 ; 1-p$, inset), leaving open the possibility that some cells may release cytochrome $c$ in the absence of Bax translocation.

\section{Discussion}

Prostate cancer is the second leading cause of cancer-related deaths of men in Western countries. Since most prostatic tumors are androgen dependent, androgen deprivation through surgical or medical castration remains the most common treatment despite their considerable side effects on sexual potency. Monotherapy with antiandrogens such as Casodex, which may preserve testosterone levels and sexual potency, has provided an attractive alternative therapeutic approach to surgical intervention. ${ }^{30}$ Unfortunately, progression to hormone refractory diseases occurs within a few years in nearly all cases. Although the underlying mechanism of Casodex-induced prostate cancer cell death has yet to be fully elucidated, the use of Casodex alone, or as adjuvant to treatment, has remain to be an attractive alternative to castration, mainly due to its quality-of-life and tolerability benefits.

Unlike TNF- $\alpha$, Casodex induces the loss of cell adhesion in LNCaP cells prior to the loss of mitochondrial activity. In 


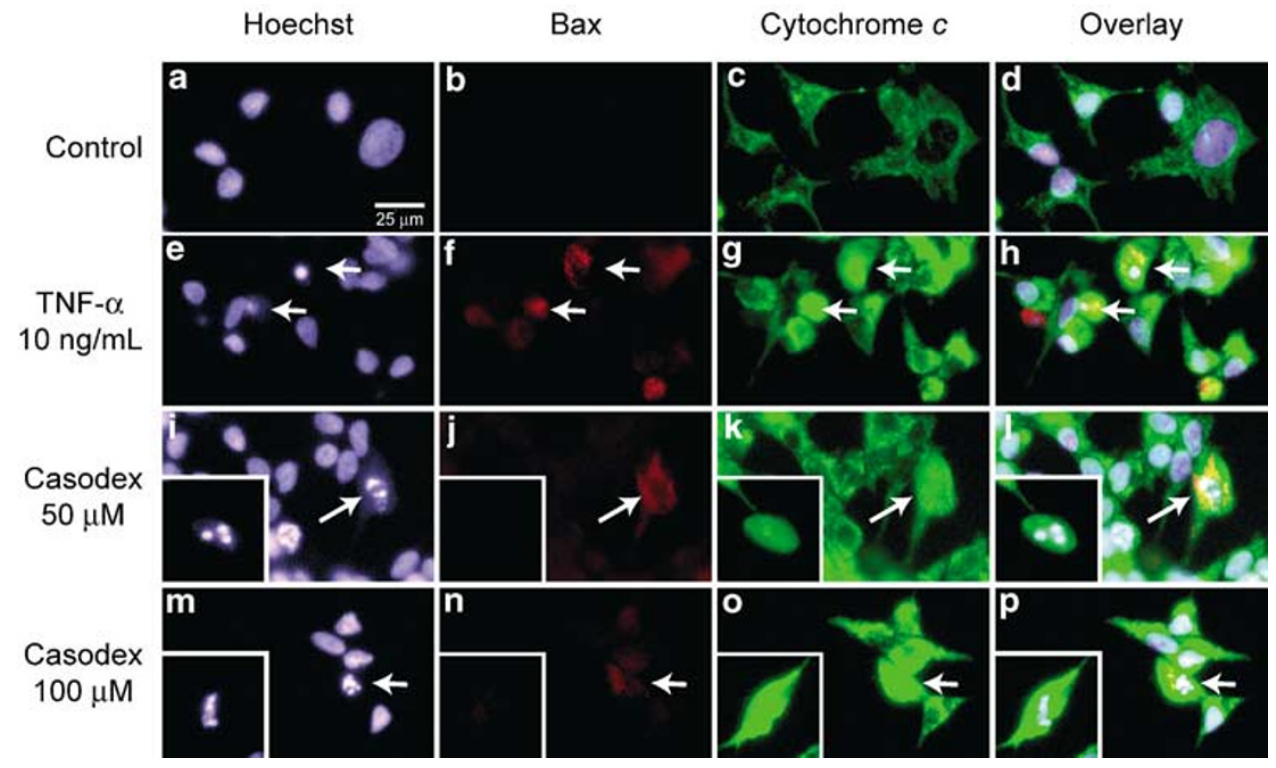

Figure 7 Effects of TNF- $\alpha$ and Casodex on cytochrome $c$ release, Bax translocation, and nuclear condensation. LNCaP cells were treated with control vehicle (a-d), $10 \mathrm{ng} / \mathrm{ml}$ TNF- $\alpha(\mathrm{e}-\mathrm{h}), 50 \mu \mathrm{M}(\mathrm{i}-\mathrm{l})$ or $100 \mu \mathrm{M}$ Casodex $(\mathrm{m}-\mathrm{p})$ for $48 \mathrm{~h}$ in Gc medium, fixed and immunostained with anticytochrome $c$ mouse monoclonal $(6 \mathrm{H} 2 . \mathrm{B} 4$, PharMingen) and anti-Bax rabbit polyclonal (06499MN; Upstate Biotech.) antibody, and visualized with anti-mouse ALEXA-488-conjugated and anti-rabbit ALEXA-568conjugated (A11001, A11036; Molecular Probes) secondary antibody respectively. Nuclei were counterstained with Hoechst 33258 (Sigma) (Bar: $25 \mu \mathrm{m}$ )

addition, the observation that Casodex is able to induce cell death without disrupting $\Delta \Psi_{\mathrm{m}}$ further demonstrates that mitochondria are unlikely to be the immediate target of Casodex-induced cell death. This suggests that after treatment with Casodex, some nonadherent cells are viable. This is further supported by the demonstration that after Casodex treatment, a small proportion of the nonadherent cells are not only viable immediately after treatment, but remain so for several weeks and are capable of cell division and colony formation. Furthermore, extracellular matrix proteases including MMP-2 and MMP-9 are upregulated in Casodex-treated LNCaP cells. ${ }^{31}$ Taken together, these data suggest that while Casodex induces cell death in most LNCaP cells, a small proportion of cells do not lose their mitochondrial membrane potential or mitochondrial dehydrogenase activity and upregulate several extracellular matric proteases, rendering them capable of invasion.

The invasive phenotype is a critical step in the progression of prostate cancer. The majority of prostate cancer patients treated with Casodex or other antiandrogens ultimately develop hormone refractory diseases and have increased propensity for metastasis. While the mechanism of Casodexinduced cell death in prostate cancer cell is presumed to be through the AR (since it is blocked by pre-incubation with an androgen analogue $R 1881)^{46}$ it is not clear how binding to AR induces apoptotic responses. Since abrogation of cell death in cancer cells has been suggested to lead to cancer progression, ${ }^{32}$ the underlying mechanism of Casodex-induced cell death needed to be fully elucidated. It has been suggested that failure of conventional androgen deprivation therapy in prostate cancer may be caused by clonal expansion of tumor cells that are able to continue androgen-dependent growth despite of low concentrations of serum androgens through the amplification or mutation of the AR gene. ${ }^{33}$ While Casodex downregulates $A R$ in the nucleus through cytoplasmic translocation and degradation, neither Bcl-2 overexpression nor TNF- $\alpha$ alter the expression or nuclear localization of AR. This suggests that neither TNF- $\alpha$ nor Casodex induce cell death simply by affecting the levels of AR expression. Furthermore, the fact that $\mathrm{Bcl}-2$ overexpression attenuates cell death induced by TNF- $\alpha$ but not Casodex suggested that increased $\mathrm{Bcl}-2$ expression seen in advance stage prostate tumor $^{25}$ is not necessary the cause of survival for hormone refractory cancer cells after antiandrogen therapy. Further studies are needed to elucidate the role of $\mathrm{Bcl}-2$ overexpression in the resistance to antiandrogen therapy.

A central component of the apoptotic machinery is a proteolytic system involving a family of proteases called caspases where activation through irreversible proteolysis of their inactive precursors (zymogens) at specific Asp residues is required. ${ }^{28}$ While TNF- $\alpha$ initiates this proteolytic system through caspase-8, Casodex appears to induce it primarily through caspase-3. Despite the uncertainties around the precise sequence of cleavage of procaspase-8, Casodex appears to induce a nonclassical cleavage product of caspase- 8 that may be due to caspase-3 cleavage of procaspase-8 at $D^{395} E A D \downarrow F^{399}$, resulting in the novel cleavage product at $45 \mathrm{kDa} .{ }^{34}$ Although capase- 8 is moderately active after Casodex treatment, it is nevertheless generated from an alternative pathway where substrate specificity of the active enzyme may be altered. This may in turn change the temporal sequence of events surrounding the activation of caspase-8 and the remainder of the apoptotic cascade and providing an opportunity for cells to avoid DNA cleavage and cell death.

The translocation and cleavage of Bax is often associated with mitochondrial disruption during apoptosis. ${ }^{29}$ We have demonstrated that the release of cytochrome $c$ after Casodex treatment is predominately associated with the translocation and clearage of Bax in a $\Delta \Psi_{\mathrm{m}}$-independent manner. Increas- 


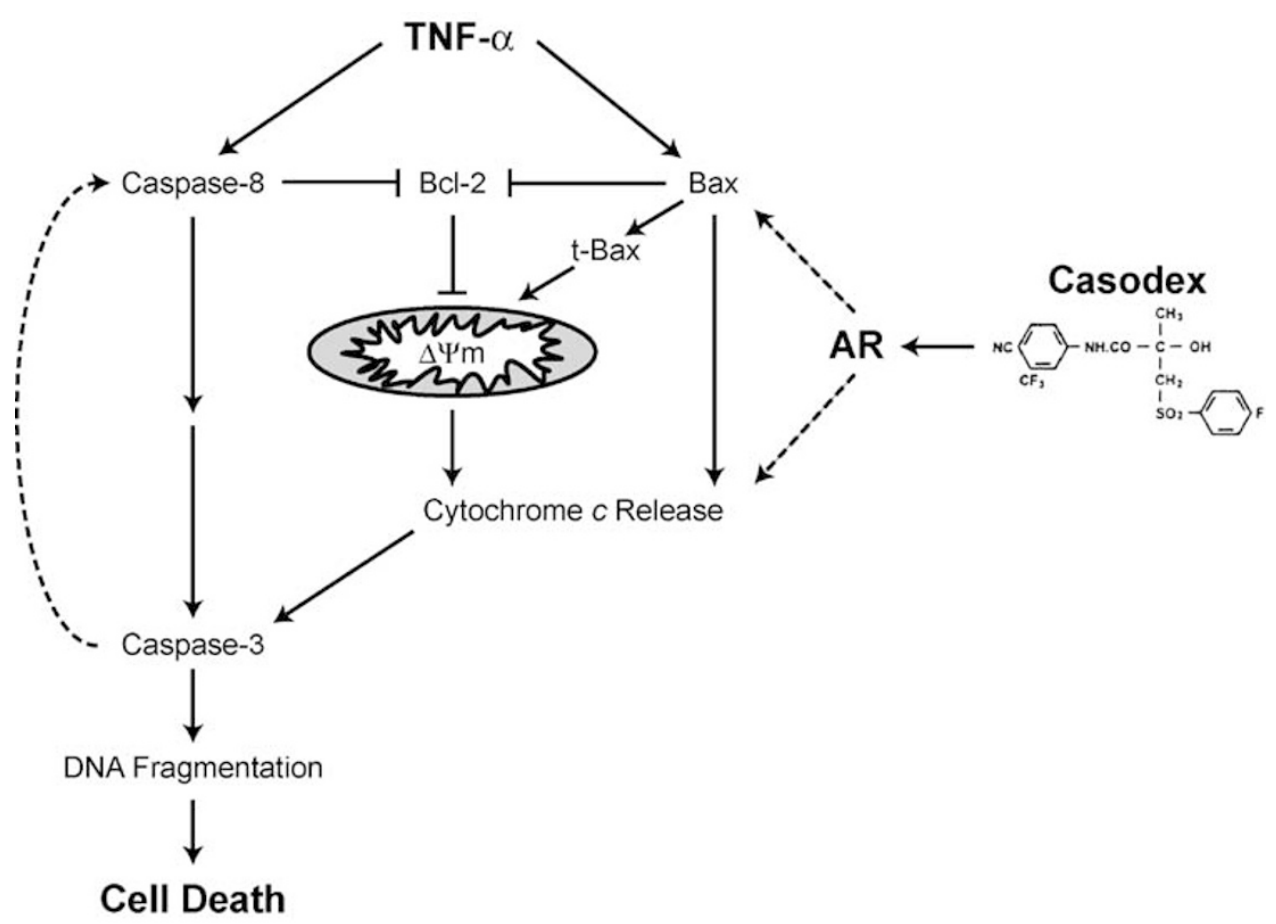

Figure 8 Schematic model of proposed mechanism of Casodex-induced cell death. Upon ligand binding of cell surface death receptors such as TNF- $\alpha$, the initiator caspase, procaspase-8 is recruited and auto-catalytically activated. Bax is also activated by cleavage to t-Bax and binds to the mitochondrial membrane, inducing the reduction of $\Delta \Psi_{\mathrm{m}}$ and the release of cytochrome $c$. The activation of caspase-8 and release of cytochrome $c$ into the cytoplasm results in the activation of caspase-3, an executioner caspase, which activates the nucleases and proteases responsible for nuclear condensation and subsequent DNA fragmentation, leading to cell death. These processes can be blocked by overexpression of Bcl-2. In contrast, Casodex induces the release of cytochrome $c$ by both Bax-dependent and -independent mechanisms (dotted arrows), resulting in the activation of caspase-3, DNA fragmentation and cell death that is independent of changes in $\Delta \Psi_{\mathrm{m}}$ and insensitive to the overexpression of anti-apoptotic Bcl-2 protein. Caspase-8 is catalytically activated by Casodex through a mechanism that is mediated by caspase-3 or other executioner caspases (dotted arrows)

ing evidence has suggested that the release of cytochrome $c$ and disruption of $\Delta \Psi_{\mathrm{m}}$ are separate events in the processes leading to mitochondrial disruption..$^{35-37}$ Whether or not mitochondria plays an essential role in the control of apoptosis is still a matter of debate. In fact, our data suggest that mitochondrial membrane transition may serve as an amplifying loop for the apoptotic process at the later stages of apoptosis but may not play a direct role in the initiation of Casodex-induced cell death. These findings lead to the hypothesis that Casodex induces cell death by acting on components downstream of the decline in $\Delta \Psi_{\mathrm{m}}$ and upstream of cytochrome $c$ release in a predominantly Bax-dependent manner (Figure 8). There is also some evidence of Baxindependent release of cytochrome $c$ after treatment with Casodex (Figure 8, inset). Whether this represents an alternative apoptotic pathway remains to be elucidated, however, there is precedent for Bax-independent cytochrome $c$ release in neural cells, isolated liver mitochondria and HL-60 cells. ${ }^{36,38-41}$

In summary, we have demonstrated that different drugs may induce cell death in the same cell line through different mechanisms that involve many or all of the same components of the apoptotic machinery, but with substantially different time courses and efficiencies. In particular, Casodex induces cell death in a lentigrade fashion that results in an extended lag phase of cell survival between the initiation of cell death and the fragmentation of DNA, during which time other survivals mechanisms may abrogate the process. This may offer the mechanistic explanation for the failure of most antiandrogen therapy in prostate cancer and the emergence of hormone refractory tumors that have high propensity for metastasis, and raises questions about the use of Casodex and other antiandrogens for neoadjuvant therapy or as chemopreventive agents.

\section{Materials and Methods}

\section{Cell culture}

LNCaP cells were maintained in RPMI- 1640 supplemented with $10 \%$ fetal bovine serum (FBS). Prior to each experiment, cells were plated in this medium, and after $24 \mathrm{~h}$ transferred to serum-free growth control (Gc) medium (RPMl-1640, $2 \mathrm{mg} / \mathrm{ml} \mathrm{BSA-V,} 1 \mathrm{ng} / \mathrm{ml}$ EGF, $0.5 \mathrm{mg} / \mathrm{ml}$ fetuin, $50 \mathrm{nM}$ hydrocortizone, $20 \mu \mathrm{g} / \mathrm{ml}$ insulin, $25 \mathrm{nM}$ sodium selenite, $0.5 \mathrm{mM}$ sodium pyruvate, $0.1 \mathrm{nM} \mathrm{T}_{3}, 10 \mu \mathrm{g} / \mathrm{ml}$ transferrin, $10 \mathrm{nM}$ testosterone) $)^{42}$ for an additional $48 \mathrm{~h}$ prior to treatment. This medium induces cell cycle arrest in $\mathrm{LNCaP}$ cells, lowering the fraction of cells in $\mathrm{S}$ phase to less then $10 \%$, mimicking the growth fraction seen in most prostate tumors in vivo. ${ }^{42}$ Cell adhesiveness was assayed by crystal violet and mitochondrial dehydrogenase activity was measured by MTT assay (Sigma, St. Louis, MO, USA).

Cells were treated with $1-10 \mathrm{ng} / \mathrm{ml}$ TNF- $\alpha$ or $10-100 \mu \mathrm{M}$ Casodex dissolved in $95 \%$ ethanol and $5 \%$ dimethyl sulfoxide (DMSO). The doses of Casodex used in these experiments $(10-100 \mu \mathrm{M})$ were chosen 
because they effectively bracket the steady-state serum concentrations $\left(C_{\mathrm{ss}}=8.9 \pm 3.5 \mu \mathrm{g} / \mathrm{ml}[30 \mu \mathrm{M}]\right)$, achieved in clinical studies with localized prostate cancer in which patients received $50 \mathrm{mg}$ Casodex once per day, ${ }^{43}$ either alone or in combination with Zoladex (an LH-RH analog). Casodex is also being used in a monotherapy regimen as an alternative treatment to castration in patients with locally advanced prostate cancer at a dose of $150 \mathrm{mg}$ Casodex/day $\left(C_{\mathrm{ss}} \approx 90 \mu \mathrm{M}\right){ }^{44}$ Thus the upper dose used in our studies $(100 \mu \mathrm{M})$ is only slightly higher than the steady-state serum levels achieved in the preclinical analysis of the pharmacokinetics of Casodex.

\section{Flow cytometry}

For analysis of $\Delta \Psi_{\mathrm{m}}$, cells treated with control vehicle, $50 \mu \mathrm{M}$ Casodex or $5 \mathrm{ng} / \mathrm{ml} \mathrm{TNF}-\alpha$ in serum-containing or serum-free medium for $48 \mathrm{~h}$ were harvested by trypsinization, resuspended in serum-containing medium with $1 \mathrm{mM}$ tetramethylrhodamine ethyl ester (TMRE, Molecular Probes, Eugene, OR, USA), incubated for $15 \mathrm{~min}$ at $37^{\circ} \mathrm{C}$, and analyzed for red fluorescence on FL3 using a $620 \mathrm{~nm}$ band-pass filter on an Epics XL Flow Cytometer. The results were modeled with the Multiplus AV software (Phoenix Flow Systems, San Diego, CA, USA).

For analysis of cell death, adherent cells were harvested by trypsinization, pooled with nonadherent cells and resuspended in serum-containing medium with $1 \mu \mathrm{g} / \mathrm{ml}$ propidium iodide $(\mathrm{PI})$. After incubation for $30 \mathrm{~min}$ at room temperature, samples were analyzed and modeled for PI fluorescence as described above.

\section{Anchorage-free cell viability assay}

LNCaP cells were treated with control vehicle, $50 \mu \mathrm{M}$ Casodex or $5 \mathrm{ng} / \mathrm{ml}$ TNF- $\alpha$ in Gc medium for $72 \mathrm{~h}$. After each treatment, nonadherent cells $\left(5 \times 10^{3}\right)$ detached from the cell culture monolayer were collected and replated on 6-well tissue culture plates $\left(9.5 \mathrm{~cm}^{2}\right.$ of growth area per well; Corning Inc., Corning, NY, USA) in RPMI-1640 supplemented with $10 \%$ FBS and $0.5 \%$ DNA grade agarose (Life Technologies, Rockville, MD, USA). Cells were incubated at $37^{\circ} \mathrm{C}$ for a further 2 weeks, at which time the number of visible colonies per well was scored as a percentage of the number of cells replated.

\section{Stable transfection}

$\mathrm{LNCaP}$ cells were stably transfected with human $\mathrm{Bcl}-2$ subcloned into pcDNA3 (Invitrogen, Carlsbad, CA, USA) or the empty vector using Lipofectin (Life Technologies). Transfected cells were selected with $400 \mu \mathrm{g} / \mathrm{ml} \mathrm{G} 418$ for 4 weeks. Independent clones were selected by serial dilution and two lines overexpressing $\mathrm{Bcl}-2$ were designated LNCaP-B10 and LNCaP-B19, respectively. Cell lines demonstrating G418 resistance and transfected with the empty vector were designated LNCaP-Neo control cells.

\section{Total cell lysate}

Total cell lysates were prepared using standard protocols. Cells were trypsinized, and pelleted by centrifugation at $1500 \times g$ for $3 \mathrm{~min}$ at $4^{\circ} \mathrm{C}$. Pellets were resuspended in Buffer A (20 mM HEPES- $\mathrm{KOH}, \mathrm{pH} 7.5$, $10 \mathrm{mM} \mathrm{HCl}, 1.5 \mathrm{mM} \mathrm{MgCl}$, $1 \mathrm{mM}$ EDTA, $1 \mathrm{mM}$ dithiothreitol, $250 \mathrm{mM}$ sucrose, $10 \mathrm{mM}$ sodium fluoride, $10 \mathrm{mM}$ sodium vanadate, $10 \mu \mathrm{g} / \mathrm{ml}$ Leupeptin, $1 \mathrm{mM}$ phenylmethylsulfonyl fluoride, $1 \mu \mathrm{g} / \mathrm{ml}$ Aprotinin and $1 \mathrm{mM}$ benzamidine), sonicated three times for $20 \mathrm{~s}$, and stored at $-80^{\circ} \mathrm{C}$. Protein concentrations were determined by the Micro BCA protein assay (Pierce, Rockford, IL, USA).

\section{Subcellular fractionation}

Subcellular fractions were isolated as previously described. ${ }^{45}$ Cells were trypsinized, and pelleted by centrifugation at $1500 \times g$ for 3 min at $4^{\circ} \mathrm{C}$. Pellets were resuspended with three volumes of Buffer $A$ and lysed with a Dounce homogenizer. Homogenates were centrifuged twice at $2000 \times g$ for $5 \mathrm{~min}$ at $4^{\circ} \mathrm{C}$ and the nuclear pellets were resuspended in Buffer $\mathrm{A}$, sonicated for $20 \mathrm{~s}$, and stored at $-80^{\circ} \mathrm{C}$. The supernatants were ultracentrifuged at $100000 \times \mathrm{g}$ for $1 \mathrm{~h}$ at $4^{\circ} \mathrm{C}$. The resultant pellets containing the mitochondria, and designated the non-nuclear membrane fractions (NNMF) were resuspended in Buffer $A$, sonicated for $20 \mathrm{~s}$, and stored at $-80^{\circ} \mathrm{C}$. The resulting supernatant containing cytosolic fraction was designated $\mathrm{S} 100$ and stored at $-80^{\circ} \mathrm{C}$.

\section{Western blot analysis}

Total cell lysate $(100 \mu \mathrm{g})$ and subcellular fractions $(100 \mu \mathrm{g})$ isolated as described above were solubilized in loading buffer containing $2.5 \% \beta$ mercaptoethanol, separated by SDS-PAGE, and transferred to nitrocellulose. Equal loading and transfer of proteins were confirmed by Ponceau-S staining (BDH, Dorset, England). Protein derived from total cell lysate, nuclear, NNMF and/or S100 extracts were immunoblotted with anti-AR rabbit polyclonal (PG-21; Upstate Biotechnology, Lake Placid, NY, USA), anti-Bcl-2 mouse monoclonal (clone 124; Upstate Biotech.), anti-Bax rabbit polyclonal (13666E; PharMingen, San Diego, CA, USA), anticaspase-3 rabbit polyclonal (06735; Upstate Biotech.), anticaspase-8 mouse monoclonal (clone 5F7; Upstate Biotech.), anticytochrome $c$ mouse monoclonal (7H8.2C12; PharMingen), anti-GAPDH mouse monoclonal (6G5; Biogenesis, Kingston, NH, USA), antilamin A/C goat polyclonal (N-18; Santa Cruz Biotech., Santa Cruz, CA, USA) or anti-ATP synthase- $\alpha$ mouse polyclonal antibodies (A11177; Molecular Probes) diluted in blocking solution (1\% heat denatured casein in PBS). Specific antibody binding was detected by goat anti-mouse (Caltag, Burlingame, CA, USA), goat anti-rabbit (BIORAD, Hercules, CA, USA), or mouse antigoat (Jackson Immuno., West Grove, PA, USA) IgG antibody conjugated with horseradish peroxidase diluted $1: 4000$ or $1: 8000$ in blocking solution and autoradiographed with enhanced chemiluminescence (Pierce). Blots were stripped with Western Re-Probe ${ }^{\mathrm{TM}}$ Buffer (Geno Technology, St. Louis, MO, USA).

\section{Caspase activity assay}

Caspase activity was analyzed with the ApoAlert Caspase Fluorescent Assay kit according to manufacturer's protocol (CLONTECH, Palo Alto, CA, USA). In brief, cytosolic extracts from $1 \times 10^{6} \mathrm{LNCaP}$ cells after treatment with control vehicle, $100 \mu \mathrm{M}$ Casodex or $10 \mathrm{ng} / \mathrm{ml} \mathrm{TNF}-\alpha$ for $48 \mathrm{~h}$ in Gc medium were incubated with $50 \mu \mathrm{M}$ DEVD-AFC or $50 \mu \mathrm{M}$ IETDAFC for $1 \mathrm{~h}$ at $37^{\circ} \mathrm{C}$ in the presence or absence of $10 \mu \mathrm{M} \mathrm{DEVD-CHO}$ or $10 \mu \mathrm{M}$ IETD-fmk. Caspase-3 and caspase-8 activities of the samples were assayed by fluorescence spectroscopy with excitation at $390 \mathrm{~nm}$ and emission at $510 \mathrm{~nm}$, of 7-amino-4-trifluoromethyl coumarin (AFC) after cleavage from the peptide substrate DEVD-AFC and IETD-AFC, respectively.

\section{Immunofluorescence}

LNCaP cells grown on Lab-Tek II chamberslides (Nalge Nunc International) were treated with control vehicle, 50 or $100 \mu \mathrm{M}$ Casodex or $10 \mathrm{ng} / \mathrm{ml} \mathrm{TNF}-\alpha$ in Gc medium for $48 \mathrm{~h}$. The cells were fixed in $3.7 \%$ formaldehyde in PBS for $5 \mathrm{~min}$ at room temperature, permeabilized in 
methanol at $-20^{\circ} \mathrm{C}$ for 6 min, and blocked overnight with $1 \%$ BSA in PBS containing $0.02 \%$ sodium azide. The slides were then incubated with anticytochrome $c$ mouse monoclonal (6H2.B4; PharMingen) and anti-Bax rabbit polyconal (06499MN; Upstate Biotech.) antibody, both diluted 1:100 in blocking buffer, for $2 \mathrm{~h}$ at $37^{\circ} \mathrm{C}$ in a humidified chamber. Slides were washed three times for 5 min with PBS followed by incubation for $1 \mathrm{~h}$ at room temperature with anti-mouse ALEXA-488-conjugated and anti-rabbit ALEXA-568-conjugated secondary antibody (photo-stable dyes with spectral properties similar to fluorescein; A11001, A11036; Molecular Probes) diluted 1:50 and 1:100 in blocking buffer, respectively. Slides were washed three times for $5 \mathrm{~min}$ with PBS, incubated for $15 \mathrm{~min}$ at room temperature with $1 \mu \mathrm{g} / \mathrm{ml} \mathrm{Hoechst} 33258$ (Sigma), washed five times for 5 min with $\mathrm{PBS}$, rinsed with $\mathrm{ddH}_{2} \mathrm{O}$, and coverslipped with an antifademounting medium (Biomeda, Foster City, CA, USA). Fluorescence was detected using Olympus AX70 microscope equipped with a Spot RT digital camera. Images were analyzed and merged using Adobe Photoshop software (Adobe Systems Inc., San Jose, CA, USA).

\section{Statistical analysis}

Data are expressed as means \pm S.D., and significance was determined by using a Student's $t$-test. A value of $P<0.05$ was considered to be significant.

\section{Acknowledgements}

The authors thank Jennifer Woyach and Christopher Thomas for technical assistance; and Dr. Carmen J. Narvaez and Dr. JoEllen Welsh for useful discussions. This work was supported by the Coleman Foundation and an award from the Department of Defense. Portions of this work were presented at the VIlth International Congress of Andrology, Montréal, Québec, Canada.

\section{References}

1. Tenniswood MP, Guenette RS, Lakins J, Mooibroek M, Wong P and Welsh JE (1992) Active cell death in hormone-dependent tissues. Cancer Metastasis Rev. 11: 197-220

2. Furr BJ (1996) The development of Casodex (bicalutamide): preclinical studies. Eur. Urol. 29: 83-95

3. Grossmann ME, Huang $\mathrm{H}$ and Tindall DJ (2001) Androgen receptor signaling in androgen-refractory prostate cancer. J Natl Cancer Inst. 93: 1687-1697

4. Knox JJ and Moore MJ (2001) Treatment of hormone refractory prostate cancer. Semin. Urol. Oncol. 19: 202-211

5. Kish JA, Bukkapatnam R and Palazzo F (2001) The treatment challenge of hormone-refractory prostate cancer. Cancer Control 8: 487-495

6. Rubben H, Bex A and Otto T (2001) Systemic treatment of hormone refractory prostate cancer. World J. Urol. 19: 99-110

7. Gross A, McDonnell JM and Korsmeyer SJ (1999) BCL-2 family members and the mitochondria in apoptosis. Genes Dev. 13: 1899-1911

8. Ashkenazi A and Dixit VM (1998) Death receptors: signaling and modulation. Science 281: 1305-1308

9. Budihardjo I, Oliver H, Lutter M, Luo X and Wang X (1999) Biochemical pathways of caspase activation during apoptosis. Annu. Rev. Cell Dev. Biol. 15: 269-290

10. Wolf BB and Green DR (1999) Suicidal tendencies: apoptotic cell death by caspase family proteinases. J. Biol. Chem. 274: 20049-20052

11. Stennicke HR, Jurgensmeier JM, Shin $H$, Deveraux $Q$, Wolf BB, Yang X, Zhou Q, Ellerby HM, Ellerby LM, Bredesen D, Green DR, Reed JC, Froelich CJ and Salvesen GS (1998) Pro-caspase-3 is a major physiologic target of caspase-8. J. Biol. Chem. 273: 27084-27090
12. Earnshaw WC, Martins LM and Kaufmann SH (1999) Mammalian caspases: structure, activation, substrates, and functions during apoptosis. Annu. Rev. Biochem. 68: 383-424

13. Slee EA, Adrain C and Martin SJ (2001) Executioner caspase-3, -6, and -7 perform distinct, non-redundant roles during the demolition phase of apoptosis. J. Biol. Chem. 276: 7320-7326

14. Janicke RU, Sprengart ML, Wati MR and Porter AG (1998) Caspase-3 is required for DNA fragmentation and morphological changes associated with apoptosis. J. Biol. Chem. 273: 9357-9360

15. Janicke RU, Ng P, Sprengart ML and Porter AG (1998) Caspase-3 is required for alpha-fodrin cleavage but dispensable for cleavage of other death substrates in apoptosis. J. Biol. Chem. 273: 15540-15545

16. Li H, Zhu H, Xu CJ and Yuan J (1998) Cleavage of BID by caspase 8 mediates the mitochondrial damage in the Fas pathway of apoptosis. Cell 94: 491-501

17. Luo X, Budihardjo I, Zou H, Slaughter C and Wang X (1998) Bid, a Bcl2 interacting protein, mediates cytochrome $c$ release from mitochondria in response to activation of cell surface death receptors. Cell. 94: 481-490

18. Desagher S and Martinou JC (2000) Mitochondria as the central control point of apoptosis. Trends Cell. Biol. 10: 369-377

19. Zou H, Li Y, Liu X and Wang X (1999) An APAF-1cytochrome $c$ multimeric complex is a functional apoptosome that activates procaspase-9. J. Biol. Chem. 274: 11549-11556

20. Shimizu S, Matsuoka $Y$, Shinohara $Y$, Yoneda $Y$ and Tsujimoto $Y$ (2001) Essential role of voltage-dependent anion channel in various forms of apoptosis in mammalian cells. J. Cell. Biol. 152: 237-250

21. Shimizu S, Shinohara $Y$ and Tsujimoto $Y$ (2000) Bax and Bcl-xL independently regulate apoptotic changes of yeast mitochondria that require VDAC but not adenine nucleotide translocator. Oncogene 19: 4309-4318

22. Wood DE and Newcomb EW (2000) Cleavage of Bax enhances its cell death function. Exp. Cell. Res. 256: 375-382

23. Wood DE, Thomas A, Devi LA, Berman Y, Beavis RC, Reed JC and Newcomb EW. (1998) Bax cleavage is mediated by calpain during drug-induced apoptosis. Oncogene 17: 1069-1078

24. Kroemer G and Reed JC (2000) Mitochondrial control of cell death. Nat. Med. 6: 513-519

25. Colombel M, Symmans F, Gil S, O'Toole KM, Chopin D, Benson M, Olsson CA, Korsmeyer S and Buttyan R. (1993) Detection of the apoptosis-suppressing oncoprotein bcl-2 in hormone- refractory human prostate cancers. Am. J. Pathol. 143: 390-400

26. Waller AS, Sharrard RM, Berthon P and Maitland NJ (2000) Androgen receptor localisation and turnover in human prostate epithelium treated with the antiandrogen, casodex. J. Mol. Endocrinol. 24: 339-351

27. Thornberry NA and Lazebnik Y (1998) Caspases: enemies within. Science. 281: $1312-1316$

28. Cohen GM (1997) Caspases: the executioners of apoptosis. Biochem. J. 326 : $1-16$

29. Zimmermann KC, Bonzon C and Green DR (2001) The machinery of programmed cell death. Pharmacol. Ther. 92: 57-70

30. Kolvenbag GJ and Nash A (1999) Bicalutamide dosages used in the treatment of prostate cancer. Prostate 39: 47-53

31. Packman K, Zhan P, Walker J, Lee E and Tenniswood M (2001) Antiandrogeninduced invasion in prostate cancer cells. In: Andrology in the 21st Century: Proceedings of the VIlth International Congress of Andrology, 2001 June 1519, 2001, Montreal, Quebec, Robaire B, HC and Morales CR. (eds), Canada: Medimond; pp. 185-195

32. Hanahan $D$ and Weinberg RA (2000) The hallmarks of cancer. Cell 100:57-70

33. Koivisto P, Kononen J, Palmberg C, Tammela T, Hyytinen E, Isola J, Trapman J, Cleutjens K, Noordzij A, Visakorpi T and Kallioniemi OP. (1997) Androgen receptor gene amplification: a possible molecular mechanism for androgen deprivation therapy failure in prostate cancer. Cancer Res. 57: 314-319

34. Muzio M, Chinnaiyan AM, Kischkel FC, O'Rourke K, Shevchenko A, Ni J, Scaffidi C, Bretz JD, Zhang M, Gentz R, Mann M, Krammer PH, Peter ME and Dixit VM. (1996) FLICE, a novel FADD-homologous ICE/CED-3-like protease, is recruited to the CD95 (Fas/APO-1) death-inducing signaling complex. Cell 85: $817-827$

35. Loeffler M and Kroemer G (2000) The mitochondrion in cell death control: certainties and incognita. Exp. Cell Res. 256: 19-26

36. Grubb DR, Ly JD, Vaillant F, Johnson KL and Lawen A (2001) Mitochondrial cytochrome $c$ release is caspase-dependent and does not involve 
mitochondrial permeability transition in didemnin B-induced apoptosis. Oncogene. 20: 4085-4094

37. Achenbach TV, Muller R and Slater EP (2000) Bcl-2 independence of flavopiridol-induced apoptosis. Mitochondrial depolarization in the absence of cytochrome c release. J. Biol. Chem. 275: 32089-32097

38. Polster BM, Kinnally KW and Fiskum G (2001) BH3 death domain peptide induces cell type-selective mitochondrial outer membrane permeability. J. Biol. Chem. 276: 37887-37894

39. Gogvadze V, Robertson JD, Zhivotovsky B and Orrenius S (2001) Cytochrome $c$ release occurs via $\mathrm{Ca}^{2+}$-dependent and $\mathrm{Ca}^{2+}$-independent mechanisms that are regulated by Bax. J. Biol. Chem. 276: 19066-19071

40. Holinger EP, Chittenden T and Lutz RJ (1999) Bak BH3 peptides antagonize $\mathrm{Bcl}-\mathrm{xL}$ function and induce apoptosis through cytochrome $c$-independent activation of caspases. J. Biol. Chem. 274: 13298-13304

41. Luetjens CM, Kogel D, Reimertz C, Dussmann H, Renz A, Schulze-Osthoff K et al. (2001) Multiple kinetics of mitochondrial cytochrome $c$ release in druginduced apoptosis. Mol. Pharmacol. 60: 1008-1019
42. Hedlund TE and Miller GJ (1994) A serum-free defined medium capable of supporting growth of four established human prostatic carcinoma cell lines. Prostate. 24: 221-228

43. Zeneca-Pharmaceuticals. CASODEX (bicalutamide) tablets Professional Information Brochure. Available at http://astrazeneca-us.com/pi/cs1075.pdf.

44. Iversen P, Tyrrell CJ, Kaisary AV, Anderson JB, Van Poppel H, Tammela TL, Chamberlain M, Carroll K and Melezinek I (2000) Bicalutamide monotherapy compared with castration in patients with nonmetastatic locally advanced prostate cancer: 6.3 years of followup. J. Urol. 164: 1579-1582

45. Narvaez CJ and Welsh J (2001) Role of mitochondria and caspases in vitamin D-mediated apoptosis of MCF-7 breast cancer cells. J. Biol. Chem. 276: 91019107

46. Zhan P, Lee EC, Packman K, Tenniswood M. Induction of invasive phenotype by Casodex in hormone-sensitive prostate cancer cells. J. Steroid Biochem Mol Biol 2002; 83: 101-111 